\title{
10. K-Ar DATES OF DEEP SEA DRILLING PROJECT SITE 608 BASALTS ${ }^{1}$
}

\author{
David E. Seidemann, Department of Geology, Brooklyn College ${ }^{2}$
}

\section{INTRODUCTION}

$\mathrm{K}-\mathrm{Ar}$ dates were obtained for three pillow basalt samples recovered from Site 608 (Samples 608-58-1, 103-109 cm; 608-59-1, 3-7 cm; 608-59-1, 48-53 cm; see Table 1). Reliable K-Ar dates cannot be routinely obtained for deep-sea igneous rocks, because they may be subject to inaccuracies related to seawater alteration (Seidemann, 1977 ) and/or the presence of excess radiogenic ${ }^{40} \mathrm{Ar}$ (Dalrymple and Moore, 1968; Dymond, 1970). Thus, the possibility that the samples dated in this study were subject to these sources of inaccuracy must be evaluated.

Submarine pillow basalts, such as those analyzed in this study, cool rapidly, sometimes preventing the escape of gases associated with the magma. The presence of excess radiogenic ${ }^{40} \mathrm{Ar}$ trapped in the rapidly cooled glassy margins of submarine pillows at the time of their formation results in anomalously high $\mathrm{K}-\mathrm{Ar}$ dates. The interiors of basalt pillows, which cool less rapidly than the margins, are frequently devoid of excess radiogenic ${ }^{40} \mathrm{Ar}$. The abundance of vesicles increases inward from the pillow margin, indicating a larger degree of degassing in the interior. There is also a systematic decrease in the excess radiogenic ${ }^{40} \mathrm{Ar}$ content of submarine basalt pillow margins with decreasing water depth of extrusion. This decrease is accompanied by an increase in the size and abundance of vesicles. The decrease in hydrostatic pressure with decreasing depth apparently promotes exsolution of dissolved gases (Dalrymple and Moore, 1968; Dymond, 1970). The presence of abundant vesicles in the pillow basalts dated in this study indicates that some degassing has occurred, making it less likely that the presence of excess radiogenic ${ }^{40} \mathrm{Ar}$ is source of inaccuracy in the $\mathrm{K}-\mathrm{Ar}$ dates obtained.

$\mathrm{K}-\mathrm{Ar}$ date-lowering related to the addition of potassium by submarine weathering has also been shown to be a major source of uncertainty in dating deep-sea basalts (Seidemann, 1977). The presence of alteration minerals in the basalt samples that were dated in this study increases the likelihood that the $\mathrm{K}-\mathrm{Ar}$ dates obtained may be inaccurate.

\section{METHODS}

Argon was extracted using a conventional extraction system with an induction furnace. The argon isotopic composition was determined

\footnotetext{
${ }^{1}$ Ruddiman, W. F., Kidd, R. B., Thomas, E., et al., Init. Repts. DSDP, 94: Washington (U.S. Govt. Printing Office).

2 Address: Department of Geology, Brooklyn College, Brooklyn, NY 11210.
}

using a Nier-type mass spectrometer with a 6-in. radius. A ${ }^{38} \mathrm{Ar}$ spike added before each analysis made possible calculation of the quantity of ${ }^{40} \mathrm{Ar}$ released from the samples. Potassium analyses were made using standard atomic-absorption techniques. The constants used in the calculation of the $\mathrm{K}-\mathrm{Ar}$ dates were as follows: $K_{\lambda \beta}=4.962 \times 10^{-10} y^{-1}$; $K_{\lambda \epsilon}=5.81 \times 10^{-11} y^{-1} ;{ }^{40} \mathrm{~K} / \mathrm{K}=0.01167$. For a more detailed discussion of the methods used, see Seidemann (1976).

\section{RESULTS}

The K-Ar dated for the three samples of oceanic pillow basalt dated in this study range from 10 to $13 \mathrm{Ma}$ (see Table 1). These dates are lower than the 42-Ma age of the sediment immediately overlying the basalt, as determined from fossil evidence (Takayama and Sato, this volume). The fossil age agrees well with the age of magnetic Anomaly 18, upon which Site 608 is located. Since the sediment deposited on these extrusive basalts must be younger than the basalts, it is clear that the $\mathrm{K}-\mathrm{Ar}$ dates are anomalously low. The $\mathrm{K}-\mathrm{Ar}$ dates obtained for these samples do not provide a true indication of the cooling age of the basalt, but probably reflect $\mathrm{K}-\mathrm{Ar}$ datelowering through potassium addition by submarine weathering. The presence of alteration minerals and potassium concentrations higher than expected for deep-sea pillow basalts are consistent with this hypothesis.

\section{REFERENCES}

Dalrymple, G. B., and Moore, J. G., 1968. Argon 40: Excess in submarine pillow basalts from Kilauea Volcano, Hawaii. Science, 161: 1132-1135.

Dymond, J., 1970. Excess argon in submarine basalt pillows. Geol. Soc. Am. Bull., 81:1229-1232.

Seidemann, D. E., 1976. $\mathrm{K}-\mathrm{Ar}$ and ${ }^{40} \mathrm{Ar} /{ }^{39} \mathrm{Ar}$ dating of deep-sea rocks [Ph.D. dissertation]. Yale University, New Haven. 1977. Effects of submarine alteration on K-Ar dating of deep-sea igneous rocks. Geol. Soc. Am. Bull., 88:1660-1666.

Date of Initial Receipt: 25 September 1984

Date of Acceptance: 28 March 1985

Table 1. K-Ar data for Site 608 basalts.

\begin{tabular}{lccc}
\hline $\begin{array}{c}\text { Sample } \\
\text { (interval in cm) }\end{array}$ & $\mathrm{K} \mathrm{( \% )}$ & $\begin{array}{c}\text { Radiogenic } \\
\times 10^{-6} \mathrm{~cm}^{3} / \mathrm{g} \mathrm{STP}\end{array}$ & $\begin{array}{c}\text { Date } \\
(\mathrm{Ma}+2 \sigma)^{\mathrm{b}}\end{array}$ \\
\hline $608-58-1,103-109$ & 1.30 & 0.53 & $10.5 \pm 0.8$ \\
$608-59-1,3-7$ & 1.64 & 0.66 & $10.4 \pm 0.9$ \\
$608-59-1,48-53$ & 1.58 & 0.80 & $13.1 \pm 1.2$ \\
& & 0.81 & $13.1 \pm 0.9$ \\
\hline
\end{tabular}

${ }^{a}$ Cubic centimeters of gas at standard temperature and pressure (STP).

$b$ Million years $\pm 2 \sigma$ standard deviation for a single analysis. 